\title{
The contingencies of whiteness: Gendered/racialized global dynamics of security narratives
}

\section{Catherine Baker}

University of Hull, UK

Both the fortification of European borders against migration from the global South and Western militaries' involvement in wars ostensibly to prevent terrorist networks reaching Western shores belong to what critical and feminist security studies already recognize as a racialized security regime. Within this gendered racial order, policies, discourses and everyday practices surrounding border security, migration, asylum and war reinforce each other to construct 'Europe' and 'the West' as normatively white spaces, under threat from racialized Others within and without (see, for example, Gray and Franck, 2019; Stachowitsch and Sachseder, 2019). Yet, on the southeastern periphery of the European Union, which was constructed as a zone of security threat in the 1990s and is now charged with securing the EU's border with the global South, identifications with whiteness are both more complex and more consequential than Western European perspectives may know them to be.

The ascription of 'whiteness', and other categories, in any system of racialization rests on imaginations that inexorably link bodily markers to descent from a certain territory of the globe and the set of cultural traits primordially associated with it in any racism's symbolic cartography of modernity, rationality and personhood (Ahmed, 2002; Mills, 1997). While the labels and details of racialized categories vary across differently geographically and historically situated 'global racisms' (Zakharov and Law, 2017: 1), all stem from hierarchies that invest whiteness with an advanced capacity for humanity and reason, and blackness with its lack. Whiteness itself has its own core and peripheries, being more stably ascribed when Northern or Germanic Europe is the imagined zone of origin than to imagined origins from the much wider hinterland where 'Europe' edges into the Mediterranean or Asia: full acceptance into whiteness thus depends on how far individuals and institutions at the core of whiteness recognize those on its peripheries as white. This phenomenon is widely perceptible across the global politics of race, known as 'contingent' (Hylton, 2018: 50), 'liminal' (Ciccariello-Maher, 2012) or 'malleable' (Christian, 2019) whiteness, or being 'white but not 
quite' (Agathangelou, 2004: 23; Alcoff, 1998: 9). Migration often exposes those who are racialized as unquestionably white in their nation of origin to being treated as not quite as white when they move - such as Central and East European migrant workers in the UK since 2004, moving from membership of an ethnonational majority defined as white into a setting of widespread xenophobia, laced with Romaphobia, towards 'East Europeans' (Fox et al., 2012: 688).

The post-Yugoslav region - traversed by the global refugee crisis's 'Balkan route' today and the site of wars that became Europe's major peace and security crisis in the 1990s - is part of this space contingently racialized as white. For critical security studies, the urge to make critical sense of the Yugoslav wars informed both the field's post-structuralist discursive turn (Hansen, 2006) and feminist theorizations of security reacting to wartime rape in Bosnia and Herzegovina $(\mathrm{BiH})$ and other forms of gender-based violence (Hansen, 2001; Zalewski, 1995). Lene Hansen's (2000: 299) feminist intervention into Copenhagen School theory took up 'Pakistani honour killings' and 'mass rapes in Bosnia' as gendered security problems it failed to notice. Alison Howell and Melanie Richter-Montpetit (2020: 6) read Hansen as, problematically in their view, representing both cases as "silent" subaltern women'. The cases, furthermore, are not interchangeable: Bosnian women are generally racialized as white, and Pakistani women generally as brown or of South Asian heritage, with opposite implications for the 'security narratives' (Wibben, 2011: 9) constructed around each group of women. Those who are Muslims, 'legible' (Lewis, 2007: 426) or not depending on their dress, are moreover perceived through lenses that are simultaneously gendered and racialized as well as religion-based. Brown Muslim women from Pakistan correspond to the prevailing popular image of 'Muslim women'; women from BiH from the South Slav ethnic group known in former Yugoslavia as 'Muslimani' ('Muslims'), now often as 'Bosniaks', tend to become "'invisible" Muslims' through their whiteness (Colic-Peisker, 2005: 628) in Western eyes - unless they wear religious dress, in which case they, like other Muslim women racialized as white, are likely to be seen as 'odd at best and dangerous at worst' (Husain, 2019: 596). Bosnian Romani women in $\mathrm{BiH}$ or abroad face various marginalizations depending on what presence Romaphobia has within racisms where they are living (Erickson, 2017).

The positions of Bosnian women and South Asian Muslim women in narratives of gender, violence and security have thus differed according to how each group has been racialized, especially when they have crossed borders in search of security or when their insecurity has been constructed as demanding international intervention. As Dženeta 
Karabegović, Slađana Lazić, Vjosa Musliu, Julija Sardelić, Elena B. Stavrevska and Jelena Obradović-Wochnik explain, writing as female scholars from the post-Yugoslav region $(\mathrm{BiH}$ and elsewhere) currently working in academia in the global North:

In these countries, we have the 'right' kind of accent and the 'right' kind of job, and we are seen as the 'good migrants'. Because we are racialised as white, people don't immediately assume we are migrants or refugees. Sometimes, it is only when they hear us speak ('Where are you really from? Oh, your English is so good!'), they realise we are. But, being racialised as white, even when they find out some of us are refugees, we are seen as 'the good migrants' because the host countries do not see us as challenging the assumed racial aesthetics. (Yugoslawomen+ Collective, 2020, emphasis in original)

The 'current refugees, asylum seekers and other unwanted migrants' at whom 'this conditional privilege given to some post-Yugoslav migrants is waved' (Yugoslawomen+ Collective, 2020) include the brown Muslim women and their families whose everyday security of making a home for themselves is undermined by immigration and social policies that weaponize white alarm over violence within Muslim families in the UK, Denmark and elsewhere.

The contingency of the whiteness ascribed to Bosnians, and other non-Romani Central and Southeast Europeans, rests in embodied and linguistic signifiers such as accent and dress, which to global Northern/Western gazes may reveal them as not belonging to whiteness on quite the same terms as members of 'core' racial and national majorities of the North/West. Though Ole Wæver and Barry Buzan (2020: 392) might list 'post-Cold War Bosnia' among “"white” examples' of 'primal/Hobbesian anarchy' to oppose Howell and Richter-Montpetit's reading the term 'primal anarchy' as 'racial discourse', turning critical attention towards how Bosnia and its people were constituted as white, rather than just contending Bosnia is white, reveals more about how security narratives were constructed after the Cold War. While Bosnians' status as white Europeans was rendered insecure by imaginaries of 'the Balkans' as a constitutive Other to 'Europe' (see Todorova, 1997), it was simultaneously stable enough for them to be welcomed and resettled more readily than the African migrants already making perilous journeys towards 'Fortress Europe' at the same time. These tensions around how Bosnians were perceived internationally required frequent reassertion of Bosnia's 'Europeanness', such as the objections of some Sarajevans to their suffering being depicted alongside that of Somalians in a wartime exhibition by a British photographer (Muppidi, 2013: 304-305). 
Better known to critical security studies are the racialized positions of Pakistani women within the global politics of security, through postcolonial feminist critique applying Gayatri Chakravorty Spivak's (1988: 297) description of 'white men saving brown women from brown men' to Western discourses after the Taliban's takeover of Afghanistan. ${ }^{1}$ These constructed women's oppression by patriarchal Muslim authorities as a sufficient security risk to justify invading Afghanistan and Iraq (Al-Ali and Pratt, 2016: 82). Here, feminist security studies became increasingly concerned with 'white women saving brown women from brown men' (Abu-Lughod, 1998: 14, emphasis added) - that is, white women's complicity in the gendered racialization of Islam, Muslims and Muslim-majority societies as threats to Western security (see Razack, 2008).

While Afghan women were the most frequent referents of these discourses, Pakistani women have also been 'contained and constructed ... within a discourse of fear and risk posed by the presence of the Muslim other' (Meetoo and Mirza, 2007: 187), especially in relation to honour killings and intra-familial violence. During the 2000s, indeed, the way in which honour killings functioned within Swedish anti-migration discourses was similar to how forced marriages functioned within such discourses in Norway and Denmark, and in 2002 only two or three years after Hansen's articles - Denmark passed 'what has been called the strictest immigration legislation in Europe' (Keskinen, 2009: 261), banning spousal migration for under-24s and introducing strict tests on 'ties to Denmark', housing and maintenance. Rendering "practices of marriage and family organization among Pakistanis (and other Muslim immigrant groups) ... suspect', it drove hundreds of couples to settle in Sweden and lead multigenerational family life 'semi-legal[ly]' through frequent stays in the DanishPakistani partner's family home (Rytter, 2011: 93), producing endemic everyday insecurity in their domestic life. Danish instrumentalization of gender-equality discourse to limit Muslim immigration and enforce Muslims' assimilation into a normatively homogeneous, Nordic and white nation fitted the transnational pattern Sara Farris (2012: 184-185) terms 'femonationalism', nationalist and neoliberal mobilizations of gender equality against Muslims and migrants from the global South. ${ }^{2}$ While South Asian and Bosnian women have similar positions in the 'migration/security nexus' (Faist, 2006) in certain respects (e.g. both needing visas to settle in the UK and the EU), the nexus's racialized politics situate South Asian Muslim women's visibility as brown and Muslim and Bosnian women's visibility as white and Muslim differently - influencing the gendered and racialized security narratives that can be told about each group. 
Whereas the post-Yugoslav region in the 1990s was a source of insecurity in European security thinking, today those tables are reversed and the region has become a site for managing insecurity that has originated elsewhere, in ways that still cast the region's place at the European centre as contingent: its governments, security forces and border regimes are tasked with policing the overland 'Balkan route' along which more than 1 million, largely Muslim, migrants and refugees have attempted to travel towards the EU since 2015 (Šabić, 2017). Here, as the Yugoslawomen+ Collective (2020) note, responsibility for fortifying the EU border falls on the region's EU member-states, candidates and neighbours, who are expected to take up the geopolitical border-guard role that EU conditionality and aid has earmarked for them since the late 1990s. Whereas socialist Yugoslavia's professed position in global racial hierarchies was within a movement of states joined in anticolonial struggle and cross-racial brotherhood, post-Yugoslav states and their leaders assert identification with Euro-Atlantic institutions based at the centre of the global North - that is, the zone of the globe that has been racialized as white. This repositioning is the product of a post-socialist forgetting of Non-Alignment across the ex-Yugoslav region (Veličković, 2012), heralded by Slovenian and Croatian intellectuals' and officials' turn away from 'Third World' solidarities in the late years of Yugoslavia itself (Kilibarda, 2010: 40).

The beginning of Kolinda Grabar-Kitarović's presidency in Croatia, coinciding with the mass expansion of the 'Balkan route', saw an assertion of overt identification with the centre of 'white' Europe through enthusiastic cooperation with the Western and European security project. Grabar-Kitarović, notably Croatia's first female president, had been elected as the Croatian Democratic Union (HDZ) candidate in January 2015 after serving as Croatian foreign minister, ambassador to the USA and (in 2011-2014) NATO's first female assistant secretary-general, where her public diplomacy portfolio had included promoting NATO's implementation of the Women, Peace and Security (WPS) agenda (Wright, 2016: 358). When seen through diplomatic photography's aesthetic convention that the leader's fashioned body represents the nation, her frequent appearances in Croatian military uniform when visiting troops in Croatia or the NATO mission in Afghanistan appeared to symbolize a Croatia that had fulfilled the dream of its founding president (and HDZ's founder): having secured independence through war in the 1990s, it was now joining Euro-Atlantic institutions where coalition members cooperated to defend their nations from transnational security threats abroad (Baker, forthcoming). Though such a 'postnational' defence represents a discourse of solidarity with civilians overseas (Kronsell, 2012: 3), postnational defence's vision of security is also inherently racialized to the extent that it divides the world into a Euro-Atlantic 
zone of peace and a zone of disorder and danger primarily located (at least in practice) in Muslim-majority states.

While Croatia's participation in NATO's International Security Assistance Force gave its military important practical frontline experience of coalition operations, and helped NATO's aim of professionalizing and modernizing post-Yugoslav armed forces, it also symbolically demonstrated that Croatia was taking an equal place with established democracies in the global North/West. Grabar-Kitarović's own background, and the steps she took to identify her public image with Croatia's military, enabled her to simultaneously personify Croatia's successful accession to NATO, NATO's WPS commitment and a Croatian military that had 'modernized' by opening up to women. Yet her identification with the WPS agenda also identified her with a reconceptualization of gender that, in normalizing counter-terrorism/counterinsurgency measures against 'Muslim' places and bodies, has been seen as a 'reproduction of racial-sexual hierarchies of power', harnessing women's agency for this racialized project (Pratt, 2013: 772).

Both wearing Croatian desert camouflage to visit troops in Kabul and Camp Marmal and embodying the 'global feminist subject' of 'cosmopolitan travel' (Kaplan, 2001) when wearing a dark suit and sandy-pink headscarf to meet Afghan President Ashraf Ghani, Grabar-Kitarović's embodied performances created a narrative of Croatia having fulfilled its founding father's dream in the re-gendered security politics of the 2010s. Yet, since the hierarchies of power inscribed in the security narratives of the War on Terror were simultaneously gendered and racialized, interpreting these performances must account for how Grabar-Kitarović's femininity and her whiteness worked together, producing an assertive white femininity that could be read as unambiguously placing Croatia on the European, Western, Northern side of the racialized lines of demarcation that have run so contingently through the post-Yugoslav space. They did so at the moment of performing Croatia's membership of a geopolitical bloc to which, under Yugoslav socialism, it had not belonged.

Such aspirations to make Croatia's belonging to a European, Western and Northern space incontrovertible have informed not just Croatian defence policy but also Croatian border policing, which has to enforce the EU's choice not to permit any legitimate means for migrants and refugees to cross its fortified external border. This 'deadly European border regime', Nicholas de Genova (2018: 1766) argues, 'immediately confronts us with the cruel (post)coloniality of the "new" Europe', where almost all movement from formerly colonized countries and other countries destabilized by European colonial projects has been made 
illegal. Croatia and other post-socialist European societies did not directly contribute to European colonialism as states - indeed were still under other empires' rule for most of that time - but in pursuing EU accession have chosen to join the EU's fortified border regime.

While Croatia's practical response to the refugee crisis was a prime ministerial, not presidential, responsibility, Grabar-Kitarović's statements and interviews still placed narratives of Croatia's role into the public sphere with presidential authority. Her interviews in autumn 2015, including one for Jutarnji list on 17 September, quickly framed the events as 'not just a humanitarian question, but also a question of national security', and explained the Croatian response was aiming to avoid 'the scenes we are seeing in Macedonia, Serbia and Hungary' where border crossings and city centres had been overwhelmed by thousands of migrants at once (Benčić, 2015). While Croatia would 'show a human face', as it had shown a 'great heart' during the Bosnian conflict, when her own family had been among those temporarily taking in Bosnian Muslim refugees, 'we must, first of all, take care of our own people', and the security services would also have to ensure no 'people who present a potential security threat' entered the country:

We know that among them, unfortunately, are also people with forged Syrian passports, who are not real refugees, but have other aims for entering the EU. (Benčić, 2015)

This allusion to ISIS militants clandestinely travelling to attack European cities had hardened by the time of her January 2017 interview with the Austrian newspaper Kleine Zeitung, following the deadliest period for ISIS-inspired terrorist attacks in the EU, into clear harmony with far-right and cultural conservative positions on Muslim refugees, including the notion that accepting them in large numbers would threaten European women's rights (see Gray and Franck, 2019). Her remarks were reported in the Croatian newspaper Jutarnji list (2017) as follows:

'Maybe this isn't politically correct, but we are making a terrible mistake if we think that people who through their whole lives in Afghanistan have learned in school and heard from religious authorities that women are less valuable than men will now, overnight, adopt our values,' said Grabar-Kitarović, who is also angry that in Europe 'there are ghettos from which the state has pulled out'.

Statements like these performed an identification with whiteness not as a physical categorization but as a 'structure of feeling' (Leonardo and Zembylas, 2013: 158), one that casts racialized Others as threats to the values of the normatively white (supra)national 
community, and to white women's security in particular. Colonialism and the Atlantic system of enslavement, which for critical race scholars represent the 'very essence' of 'European modernity' (Danewid, 2017: 1679), both took their affective texture from such gendered and racialized security narratives. Though Central and Southeast Europeans' national ancestors were far less involved in creating empire abroad than the Western European polities that became imperial metropoles, joining Euro-Atlantic institutions since the end of the Cold War has largely meant leaders acquiescing in what that European colonial project has become, rather than envisioning emancipatory alternatives to it. For Hungarian Prime Minister Viktor Orbán, it has even meant creating a vision that has become a right-wing alternative to EU cosmopolitanism (Kalmar, 2018), simultaneously resisting Muslim immigration, the supposed Jewish influence of 'Soros funding', media and academic freedom, feminism, and LGBTQ rights.

Appreciating the specific histories and contingencies of 'race' from nation to nation enables critical security studies to theorize racism with these complexities in mind. By way of example, we can return to Howell and Richter-Montpetit's (2020: 6) commentary on how, in their view, Hansen's reliance Bosnian and Pakistani examples to critique Copenhagen School theory 'elides gendered insecurity in places like Denmark'. The contention then becomes whether these groups of women 'are deemed to be silent' (Howell and Richter-Montpetit, 2020: 6) in Hansen's own scholarly voice or because national optics and threatening and violent actors have silenced them (Hansen, 2020: 381-382). Hansen's (2020: 383) rejoinder asserted that her wider research on securitization and wartime rape in $\mathrm{BiH}$ (Hansen, 2001) had connected to gendered insecurities in her home society by illustrating the problem that peacetime rape, as opposed to wartime rape, was not being constituted as a 'collective security problem'. It had thus, to that extent, addressed gendered insecurities in Denmark, though had not noted the beginnings of the racialized gendered insecurities that would crystallize into the 'femonationalist' tightening of immigration laws after right-wing alarm about forced marriages, and the system of 'coercive assimilation' (Jaffe-Walter, 2017) through daycare and education that followed, during Denmark's 2000s and 2010s.

For critical security studies to seek out such racialized gendered insecurities in this example requires appreciating how racism and gender (and class) have 'interlocked' (Collins, 1993: 31) in Denmark to create specific forms of insecurities affecting women, and people of other genders, from Muslim backgrounds. It also requires understanding how race and whiteness contributed to identity construction in late 20th-century Danish progressive and peace movements (where the Copenhagen School originated; see Tunander [2008: 171]), an 
important dimension of antiracist movements' history (Lentin, 2004). Yet interpretations of the contention between Howell and Richter-Montpetit and Hansen that turned solely on contrasting how Hansen's analysis covered Bosnian and Pakistani women on one hand and how far it covered Denmark on the other would risk producing an incidental 'bosniaandpakistan' by collapsing those first two contexts into each other (the move Cynthia Enloe [2014: 1] observes being made for conflations of 'womenandchildren'); one might, instead, pause to consider each group's position within global configurations of race.

Asking how Bosnian and Pakistani women have each been racialized in the migration/security nexus, and how Croatia's first female president aligned her public persona and thereby her nation with Euro-Atlantic institutions' racialized security projects, illustrates the post-Yugoslav region's changing significance in European security politics between the 1990s and today. Even more importantly for an antiracist critical security studies, they show that the contingency of whiteness is a salient factor in the production of security narratives. Not only do the categories, spectrums and meanings of particular embodied signifiers vary from place to place, within racism's underlying structuring opposition of 'white' and 'black', but the very idea of 'Europe' that critical race perspectives invoke covers spaces with very different relationships to colonial histories. By recognizing global inflections of race in their full complexity, a reparative approach to race, racism and coloniality in critical security studies can redress both the systemic 'epistemic injustice' affecting postcolonial, decolonial and antiracist scholarship (Zondi, 2018: 22) and the overlooking of the 'particularities of postsocialist contexts' that even transnational postcolonial feminism often enacts (Tlostanova et al., 2019: 81). If the complexities of racialization in the post-Yugoslav region force us to make specifically national frameworks of race visible in order to see race at work there at all, articulating what is locally and nationally specific in any racism helps to create a globally antiracist critical security studies, alive to how systems of racialization have been translated around the world.

\section{References}

Abu-Lughod L (1998) Introduction: Feminist longings and postcolonial conditions. In: Abu-

Lughod L (ed.) Remaking Women: Feminism and Modernity in the Middle East.

Princeton, NJ: Princeton University Press: 3-32.

Agathangelou AM (2004) The Global Political Economy of Sex: Desire, Violence and

Insecurity in Mediterranean Nation States. Basingstoke: Palgrave Macmillan. 
Ahmed S (2002) Racialized bodies. In: Evans M and Lee E (eds) Real Bodies: A Sociological Introduction. Basingstoke: Palgrave Macmillan: 46-63.

Al-Ali N and Pratt N (2016) Positionalities, intersectionalities and transnational feminism in researching women in post-invasion Iraq. In: Wibben ATR (ed.) Researching War:

Feminist Methods, Ethics and Politics. London: Routledge: 76-91.

Alcoff LM (1998) What should white people do? Hypatia 13(3): 6-26.

Baker C (forthcoming) Celebrity leader personas and embodied militarism. International Studies Review. Epub ahead of print 2 July 2020. DOI: doi.org/10.1093/isr/viaa035.

Benčić L (2015) Hrvatska će pomoći, ali sigurnost hrvatskih građana je na prvom mjestu [Croatia will help, but Croatian citizens' security comes first]. Jutarnji list (Zagreb), 17 September. Available at: https://www.jutarnji.hr/vijesti/hrvatska/predsjednicaekskluzivno-za-jutarnji-hrvatska-ce-pomoci-ali-sigurnost-hrvatskih-gradana-je-na-prvommjestu-301372 (accessed 19 January 2021).

Christian M (2019) A global critical race and racism framework: Racial entanglements and deep and malleable whiteness. Sociology of Race and Ethnicity 5(2): 169-185.

Ciccariello-Maher G (2012) The dialectics of standing one's ground. Theory and Event 15(3). Available at: https://muse.jhu.edu/article/484431 (accessed 18 January 2021).

Colic-Peisker V (2005) 'At least you're the right colour': Identity and social inclusion of Bosnian refugees in Australia. Journal of Ethnic and Migration Studies 31(4): 615-638.

Collins PH (1993) Toward a new vision: Race, class, and gender as categories of analysis and connection. Race, Sex and Class 1(1): 25-45.

Danewid I (2017) White innocence in the Black Mediterranean: Hospitality and the erasure of history. Third World Quarterly 38(7): 1674-1689.

De Genova N (2018) The 'migrant crisis' as racial crisis: Do Black Lives Matter in Europe? Ethnic and Racial Studies 41(10): 1765-1782.

Enloe C (2014) Bananas, Beaches and Bases: Making Feminist Sense of International Politics, 2nd edn. Berkeley, CA: University of California Press.

Erickson J (2017) Intersectionality theory and Bosnian Roma: Understanding violence and displacement. Romani Studies 27(1): 1-28.

Faist T (2006) The migration-security nexus: International migration and security before and after 9/11. In: Bodemann YM and Yurdakul G (eds) Migration, Citizenship, Ethnos. Basingstoke: Palgrave Macmillan: 103-119.

Farris S (2012) Femonationalism and the 'regular' army of labor called migrant women. History of the Present 2(2): 184-199. 
Fox JE, Moroşanu L and Szilassy E (2012) The racialization of the new European migration to the UK. Sociology 46(4): 680-695.

Gray H and Franck AK (2019) Refugees as/at risk: The gendered and racialized underpinnings of securitization in British media narratives. Security Dialogue 50(3): 275291.

Hansen L (2000) The Little Mermaid's silent security dilemma and the absence of gender in the Copenhagen School. Millennium 29(2): 285-306.

Hansen L (2001) Gender, nation, rape: Bosnia and the construction of security. International Feminist Journal of Politics 3(1): 55-75.

Hansen L (2006) Security as Practice: Discourse Analysis and the Bosnian War. London: Routledge.

Hansen L (2020) Are 'core' critiques of securitization theory racist? A reply to Alison Howell and Melanie Richter-Montpetit. Security Dialogue 51(4): 378-385.

Howell A and Richter-Montpetit M (2020) Is securitization theory racist? Civilizationism, methodological whiteness, and antiblack thought in the Copenhagen School. Security Dialogue 51(1): 3-22.

Husain A (2019) Moving beyond (and back to) the black-white binary: A study of black and white Muslims' racial positioning in the United States. Ethnic and Racial Studies 42(4): 589-606.

Hylton K (2018) Contesting 'Race' and Sport: Shaming the Colour Line. London: Routledge. Jaffe-Walter R (2017) 'The more we can try to open them up, the better it will be for their integration': Integration and the coercive assimilation of Muslim youth. Diaspora, Indigenous, and Minority Education 11(2): 63-68.

Jutarnji list (Zagreb) (2017) 'Mislim da smo primili pogrešne izbjeglice, u Europu su većinom došli za borbu sposobni muškarci, što je s majkama koje su ostale u Alepu?' ['I think we've taken the wrong refugees, mainly battle-ready men came to Europe, what about the mothers who stayed in Aleppo?']. 16 January. Available at: https://www.jutarnji.hr/vijesti/hrvatska/mislim-da-smo-primili-pogresne-izbjeglice-ueuropu-su-vecinom-dosli-za-borbu-sposobni-muskarci-sto-je-s-majkama-koje-su-ostale-ualepu-5514491 (accessed 19 January 2021).

Kalmar I (2018) 'The battlefield is in Brussels': Islamophobia in the Visegrád Four in its global context. Patterns of Prejudice 52(5): 406-419.

Kaplan C (2001) Hillary Rodham Clinton's Orient: Cosmopolitan travel and global feminist subjects. Meridians 2(1): 219-240. 
Keskinen S (2009) 'Honour-related' violence and Nordic nation-building. In: Keskinen S, Tuori S, Irni S and Mulinari D (eds) Complying with Colonialism: Gender, Race and Ethnicity in the Nordic Region. Farnham: Ashgate: 257-272.

Kilibarda K (2010) Non-aligned geographies in the Balkans: Space, race and image in the construction of new 'European' foreign policies. In: Kumar A and Maisonville D (eds) Security Beyond the Discipline: Emerging Dialogues on Global Politics. Toronto: York Centre for International and Security Studies, 27-57.

Kronsell A (2012) Gender, Sex, and the Postnational Defense: Militarism and Peacekeeping. Oxford: Oxford University Press.

Lentin A (2004) Racism and Anti-Racism in Europe. London: Pluto.

Leonardo Z and Zembylas M (2013) Whiteness as technology of affect: Implications for educational praxis. Equity and Excellence in Education 46(1): 150-165.

Lewis R (2007) Veils and sales: Muslims and the spaces of postcolonial fashion retail. Fashion Theory 11(4): 423-441.

Meetoo V and Mirza HS (2007) 'There is nothing "honourable” about honour killings': Gender, violence and the limits of multiculturalism. Women's Studies International Forum 30(3): 187-200.

Mills CW (1997) The Racial Contract. Ithaca, NY: Cornell University Press.

Mirza N (2016) The UK government's conflicting agendas and 'harmful' immigration policies: Shaping South Asian women's experiences of abuse and 'exit'. Critical Social Policy 36(4): 592-609.

Muppidi H (2013) On The Politics of Exile. Security Dialogue 44(4): 299-313.

Pratt N (2013) Reconceptualizing gender, reinscribing racial-sexual boundaries in international security: The case of UN Security Council Resolution 1325 on 'Women, Peace and Security'. International Studies Quarterly 57(4): 772-783.

Razack SH (2008) Casting Out: The Eviction of Muslims from Western Law and Politics. Toronto: University of Toronto Press.

Rytter M (2011) Semi-legal family life: Pakistani couples in the borderlands of Denmark and Sweden. Global Networks 12(1): 91-108.

Šabić SŠ (2017) The impact of the refugee crisis in the Balkans: A drift towards security. Journal of Regional Security 12(1): 51-74.

Spivak GC (1988) Can the subaltern speak? In: Nelson C and Grossberg L (eds) Marxism and the Interpretation of Culture. Urbana-Champaign, IL: University of Illinois Press, 271-313. 
Stachowitsch S and Sachseder J (2019) The gendered and racialized politics of risk analysis: The case of Frontex. Critical Studies on Security 7(2): 107-123.

Tlostanova M, Thapar-Björkert S and Koobak R (2019) The postsocialist 'missing other' of transnational feminism? Feminist Review 121(1): 81-87.

Todorova M (1997) Imagining the Balkans. Oxford: Oxford University Press.

Tunander O (2008) Geopolitics of the north: Geopolitik of the weak: A post-Cold War return to Rudolf Kjellén. Cooperation and Conflict 43 (2): 164-184.

Veličković V (2012) Belated alliances? Tracing the intersections between postcolonialism and postcommunism. Journal of Postcolonial Writing 48(2): 164-175.

Wæver O and Buzan B (2020) Racism and responsibility - The critical limits of deepfake methodology in security studies: A reply to Howell and Richter-Montpetit. Security Dialogue 51(4): 386-394.

Wibben ATR (2011) Feminist Security Studies: A Narrative Approach. London: Routledge. Wright KAM (2016) NATO's adoption of UNSCR 1325 on Women, Peace and Security: Making the agenda a reality. International Political Science Review 37(3): 350-361. Yugoslawomen+ Collective (2020) The tale of 'good' migrants and 'dangerous' refugees. The Disorder of Things, 19 July. Available at: https://thedisorderofthings.com/2020/07/19/17977/ (accessed 19 January 2021).

Zakharov N and Law I (2017) Post-Soviet Racisms. London: Palgrave Macmillan.

Zalewski M (1995) 'Well, what is the feminist perspective on Bosnia?' International Affairs 71(2): 339-356.

Zondi S (2018) Decolonising International Relations and its theory: A critical conceptual meditation. Politikon 45(1): 16-31. 


\section{Notes}

${ }^{1}$ Spivak was referring to 19th-century British imperial justifications of the 'civilizing mission' in South Asia, which promised to stamp out the Hindu practice of sati.

2 A parallel 'intertwining of gender equality and immigration control' (Mirza, 2016: 598) in the UK, where alarm over 'sham marriages' led to a two-year probationary period for spousal visas in 2003, meanwhile limited the ability of women who did not benefit from EU freedom-of-movement rules to leave abusive relationships. 